\title{
The Power of a Leader in the Samin People's Opposition Movement to the Development of a Cement Factory in the North Kendeng Mountains
}

\author{
Enkin Asrawijaya'; Bambang Hudayana² \\ ${ }^{1}$ Faculty of Education and Teaching, Institut Agama Islam Bakti Negara (IBN) Tegal, Indonesia \\ ${ }^{2}$ Faculty of Cultural Sciences, Universitas Gadjah Mada, Indonesia \\ Corresponding Author: bambang.hudayana@ugm.ac.id
}

\begin{abstract}
This paper explores the role of a leader in the Samin people's opposition movement to the construction of a cement factory in the Kendeng Mountains, Java, Indonesia, using Agency Theory. Using Agency Theory can readily explain why the Samin people, who undertook passive opposition to state hegemony, were later able to undertake active and open opposition. Agency became an important factor enabling the Samin people to mount an opposition that was active, open and organized. This agency is about the person of Gunretno. Data were collected using the interview and participation-observation methods. Interviews were conducted regarding a leader who acted as an agent for opposition actions, and with informants drawn from Samin residential circles and stakeholders who supported the Samin people's opposition movement. The results revealed that agency is a major contributor to interpreting an opposition movement's ideological formulation, development of networks, stakeholder support, opposition movement actions of advocacy, and peaceful demonstrations. The Samin people's opposition actions enhanced their credibility, thus contributing to their movement's victories through the courts. These findings contribute to social movement theory, particularly in relation to farmers' movements and traditional communities.
\end{abstract}

Keywords: agency; cement factory; demonstration; Samin people's movement

\section{INTRODUCTION}

The wave of opposition to the cement factory extractive practice plan in the Kendeng Mountains by the Samin community or often called Sedulur Sikep in Pati, Central Java is ongoing. The movement is a form of reproduction of the idea, which originates from Adam's teaching which emerged in the colonial era (Aziz, 2012; Putri, 2017), of using non-violent means, as taught by their ancestors, to love harmony (Darmastuti, 2015). Aside from this, the issues of livelihood and environment are the main problems which gave birth to this movement (Asrawijaya, 2020; Putri, 2017; Setiadi et al., 2017; Suharko, 2016)a shift has occurred in the Sedulur Sikep communitys attitude since the increase in its popularity and coverage in the mass media following its involvement in the anti-cement movement in Central Java. However, not all members of Sedulur Sikep participate in or even approve of this movement. This anthropological study attempts to illustrate how this situation has pushed the Sikep community members to (re. On this basis, agency emerged becoming the driving force of the Samin movement opposition in rejecting the cement factory (Asrawijaya, 2020; Putri, 2017; Setiadi et al., 2017; Suharko, 2016)a shift has occurred in the Sedulur Sikep communitys attitude since the increase in its popularity and coverage in the mass media following its involvement in the anti-cement movement in Central Java. However, 
not all members of Sedulur Sikep participate in or even approve of this movement. This anthropological study attempts to illustrate how this situation has pushed the Sikep community members to (re.

Prior to opposing the establishment of a cement factory, Samin people were known as a group of farmers with a culture of opposing state hegemony in the vicinity of Kendeng Mountains covering Blora, Kudus, Purwodadi, Grobogan, Pati and Bojonegoro, Ngawi, Tuban, and Madiun (Asrawijaya, 2020; Novianto, 2018; Putri, 2017; Setiadi et al., 2017, Suharko, 2016). Historically, the culture of opposition was born from the frustration experienced by Javanese farmers in the Dutch colonial period, a consequence of the high tax burden placed on the farmers, as a result they fled to the interior, out of reach of the colonial government (Ba'asyin \& Ba'asyin, 2014).; King, 1977; Korver, 1976; King, 1973; Benda \& Castles, 1969).

The founder of the Samin community was Samin Surosentiko, and for this reason the community is known by his name (Ba'asyin \& Ba'asyin, 2014; Benda \& Castles, 1969). Samin came from a farming community which fled to a forested area so as escape colonial control in the 19th century. They formed an egalitarian community which had a tradition of passive resistance (Ba'asyin \& Ba'asyin, 2014; Peluso, 1992; Benda \& Castles, 1969).

The Samin people's passive resistance was conducted by means of opposing obligations imposed by the state such as paying taxes and choosing egalitarianism hence using the lowest level of the Javanese language, ngoko as an egalitarian language when speaking to authorities or even to others (Susilo, 2003; Widodo, 1997; Winarno, 2003). The Samin people's position of refusing to pay taxes, and practicing an egalitarian culture, meant a negative stigma attached itself to them, for example they are stereotyped as stupid, indifferent, and uncivilised. (Aziz, 2012).

Samin's teachings developed in a tradition which extols nature, where for the community the earth is the giver of life thus in cultivating rice fields and other produce of nature it is done as needed, not exploited to excess, always ensuring a natural balance to preserve nature. For this reason, becoming a farmer is a Samin community is a life choice providing a harmonious life between man and nature (Subarkah \& Wicaksono, 2013). Becoming a farmer is also a symbol of simplicity and honesty as a human who does not commit wrong through a simple life.

Since independence Samin people also continued to wage passive resistance to state domination from the Indonesian State Forestry Company (Perhutani -
Perusahaan Hutan Negara Indonesia) which threatened their existance (Peluso, 1992). They strengthened their identity as the Samin Group to consolidate their position to reject Perhuni's control over the forests in their area, which had impoverished them. The Samin people remain living in Perhutani's forest area and are reluctant to work with them as though it were working on the company's land.

In the New Order period, state control of villages was every increasing both in development and in the administrative areas and community. Antlov, 1995). Consequently, the Samin community felt the presence of the village administrative role which represented the state's role (Faturrohman, 2003; Fauzanafi, 2012). The Samin community then became increasingly opened up because of the inclusion of a development program in the villages.

The Samin people began to feel a threat from the presence of the state at the time economic development programs exploited resources in the area. This emerged strongly at the beginning of the reformation era. Regional autonomy had pushed regional governments to open the investment tap in the mining sector (Hartati, 2012). There were two cement companies which planned to establish factories in the Kendeng Mountains, that is Semen Gresek Limited which changed its name to PT Semen Indonesia (SI) and Sahabat Mulia Sakti Limited (PT SMS). They rejected these companies because they threatened the local economy and would damage the environment. Samin opposition to the mining companies got the support of several elements of civil community movements (Putri, 2017; Suharko, 2016).

This paper takes the view that the success of the Samin people in opposing the establishment of the cement factories was because there was a person of agency, that is Gunretno as the leader of the opposition, through advocacy and participation. The opposition movement showed that the Samin people did not conduct a passive resistance as in the Samin Surosentika period.

Several previous studies mention a figure named Gunretno as a leader of the Samin movement (Putri, 2017; Setiadi, Saraswati, \& Rosyid, 2017; Suharko, 2016) Central Java since 2010. Using secondary data collected from off line and on line media, and applying Wehr's model of conflict mapping, the article aims to map the conflict. For the corporation, karst can be mined and has a high economic value. For Sedulur Sikep, karst must be concerved because it covers water reservoir that is vital for its agricultural livelihood. From 2010 to 2014, while Sedulur Sikep continuesly rejected the establishment of the plant, PT SMS had completed environmental 
impact analysis. After Head of Pati district launched an environmental licence for PT SMS in the end of 2014, the two parties of conflict had been head to head in two levels of the administrative courts (PTUN Semarang and PTTUN Surabaya. Other studies show that the Samin movement is motivated by its ideological force as the basis for action (Aziz, 2012; Darmastuti, 2015). Nevertheless, their studies do not position Guretno as a powerful agency.

To delve more deeply into the role of agency in the Samin people's opposition movement, this paper will pose the following questions. First, what is the social context of Gunretno as a powerful agency in the opposition movement? Second, how does agency design and keep the Samin residents opposition actions to demonstrative means without violence? Third, how is the success of the Samin movement, in resisting the establishment of the cement factory, due to this role of agency?

\section{THEORETICAL FRAMEWORK}

This paper uses two theories which have synergies that is Agency Theory and Social Movement Theory. Agency Theory is used to explain how the emergence of new agency from the Samins as a result provides an ability to mobilize the Samin community to oppose by means of advocacy and participation as a form of opposition from a social movement. Agency Theory is used to explain Gunretno's capacity as a figure whose Samin people's opposition movement opposed the cement factory.

The concept of agency is understood in a theoretical framework concerning actions. Bourdieu (1990) views that man's social actions are influenced by structure and agency. The structure has various meanings but according to Giddens (1994) structure is regulation and resources. Rules or regulations cover both written and unwritten norms. Meanwhile, resources are twofold, that is allocative and authoritative resources. Allocative resources are material resources whereas authoritative resources are non-material, such as status. These resources are used by agents to make actors do what is expected (Kinseng, 2017). In this article, structure refers to Samin ideology and concurrently stakeholders who can be used by the agent to influence the actions of the actors.

This article also takes the view that agents are individuals who have the ability to manipulate the rules and resources so actions taken are in accordance with their expectations (Kinseng, 2017). According to Sewell (1992) agency are individuals who have an ability to control social relations, and transform these social relations. This ability can be in the form of skills in using social capital for mass mobilization (Bourdieu, 1990). Aside from this, agency has a strong strategy because it can integrate old and new strategies, a form of innovation (Wang \& Soule, 2016). No less important, agency also becomes a powerful person because of possessing powers of creativity, innovation and extensive knowledge (Giddens, 1984).

Although both became leaders of a movement, Gunretno is different to Samin Surosentiko, his predecessor who successfully established the Samin community. Theoretically, Samin Surosentiko used a power based on charisma and ideology in motivating his loyal and brave members to passively oppose the state. This paper adopts the view that Gunretno developed his influence by using social capital, a capital which is often used by new social movement activists in galvanizing political support from their colleagues (Harsasto, 2020).

In possessing social capital as a political force, Gunretno can be separated from the reformation political context which contributed to the growth of civil community movements. Buechler (1995) explains that civil society opposes state domination and the free market in a social movement framework. A social movement is defined as those political social activities of a community group to fight for its interests, in the public sphere, by means of developing alliances with its supporters to pressure the side which takes away their rights (Davis, McAdam, Scott, \& Zald, 2005).

Democracy has allowed the growth of various social movements driven by civil society organizations (Tandon $\&$ Mohanty, 2002). The agenda of social movements is very wide, but basically civil community organizations work to fight for community interests against a state regime and the market. When taking political action, a social movement gets political support from various civil community elements within and outside the country (Saturnino, Edelmen, \& Kay, 2010; Subono, 2017).

There are many studies which discuss civil society resistance to the state and the global market. In Mexico, for example the Zapastista movement was born which involved the Chiapas community opposing the oil company, Petroleos Mexicanos (Azhima, 2011), the Cristero community opposing the Plutarch government which allowed oil drilling by US companies (Butler, 2006). In Ecuador, the Amazon traditional community movement was born opposing the Coldeco company mining project (Sacher \& Baez, 2016). In Zimbabwe, the Shona and Ndebele tribal movement emerged as a response to the ever increasing loss of their farming land from industrialization (Moyo, 2005), and the Chimurenga people also oppose mining practices by the British South Africa Company (Kaoma, 2016). Whereas in India, there 
is the Odisha people's opposition to a mineral mining project (Kaoma, 2016).

In Indonesia, civil society movements opposing neoliberalisme, in contrast more often tells the story of a traditional society's opposition so as to defend their land rights. These movements can be seen in Savitri's study (2013) concerning the opposition of the Marind people in the face of the Merauke Integrated Food and Energy Estate (MIFEE) project in Papua. Rahab (2010) discusses the struggle of the Amungme tribe opposing Freeport. Ruswiastuti, Fauzi, and Bacriadi (1997) and Supraha (1998) discuss the Selasih traditional community's opposition to investors taking their land in Bali. Robinson (2016), discusses the traditional community's opposition in Battang Palopo and Sorowako, South Sulawesi opposing a mining company.

This paper studies the Samin people's social movement. First, previous studies very much bring to the fore ideological force as a factor in motivating the Samin people in opposing extractive businesses (Aziz, 2012; Darmastuti, 2015). In contrast, this study focuses on how the role of agency, as a motivator of social action, can proceed. Second, although the focus is on the role of agency, this study differs from Hudayana, Suharko and Widyanta's (2020) which focusses on communal violence which is seen as agency and residents maneouvering to obtain material compensation. In addition, their study does not examine social movements. In contrast, this paper considers opposition actions through advocative and demonstrative means, and studying social movements.

This paper looks at how agency plays an important role in opposing with demonstrative means without communal violence. The role of agency becomes apparent in several Samin people's opposition actions which continued for more than 10 years. By examining the process over 10 years it will become apparent what Guretno's, the community's, and stakeholders roles were in galvanizing opposition to the establishment of a cement factory resulting in stopping further planning for this factory.

This paper also views Gunretno as an agent who can use civil society support to increase his influence over the community resulting in the community taking opposition actions in advocative and participative ways. Gunretno was also able to use civil community organizational support to gain strong influence in the pressuring of the government and cement companies.

\section{RESEARCH METHOD}

The field research was conducted in Baturejo Village,
Sukolilo sub-district, Pati Regency, Central Java, between August 2018 to January 2019. The research method was ethnographic, placing more focus on the life history of the leading figure of agency. The collection of data was more on the accuracy and the truth of the information which was conveyed by the main figure, based on his experiences in organizing social movements. Other information was also obtained from informants who explained various experiences in undertaking protests or supporting the Saman people's opposition to the development of a cement factory. The sources of data are categorized into several groupings. This can be seen in table 1 .

To obtain data about the opposition strategy, the researcher undertook participant observations research and accordingly joined in following opposition movement activities over the period 2018 to 2019. The researcher participated in five field actions with the remainder of the data based on secondary sources from both printed and electronic newspapers.

By using social movement theory, in particular concerning the role of agency, the research often references an agent who influenced stakeholders' and actors' actions. The agent referred to in this research is Gunretno, as it is Gunretno who had a role not only as a motivating actor but a greater role as a facilitator both in creating a network and in selecting the movement's strategy.

\section{RESULT AND DISCUSSION}

\section{Samin People in Kendeng Mountains and their Ideology}

The Kendeng Mountains are an expanse of karst hills spread out extensively in the northern part of Java. Based on the Energy and Mineral Resources (ESDM Energi dan Sumber Daya Mineral) Ministerial Decision No. $0398 / \mathrm{K} / 40 / \mathrm{MEM} / 2005$, the karst region is known as a protected space which cannot be exploited, it is a protected area.

The Kendeng area is an administrative region of Pati, Rembang, Blora, Kudus and Grobogan Regencies, Central Java. Orang Samin are mostly found in the Sukolilo sub-district, Pati Regency. In Sukolilo subdistrict there are villages which have many Samin people, that is Baturejo and Sukolilo villages. In these villages the Javanese population is about 15000 people while the Samin people reach around 1200 people or about 8 percent of the total population of these villages.

The Samin people practice an egalitarian and self-sufficient life, and unlike the Javanese do not form 
Table 1. Source of Data, Number of Informants and Main Themes for Questions

\begin{tabular}{|c|c|c|c|}
\hline No & Source of Data & Method & Main Themes for Questions \\
\hline 1 & $\begin{array}{l}\text { Agency (the } \\
\text { figure of } \\
\text { Gunretno) }\end{array}$ & In-depth Interviews & $\begin{array}{l}\text { Discourse which was developed in the rejection of the cement factory } \\
\text { The communication which was developed in the mobilization of the masses and the } \\
\text { spreading of the ideology } \\
\text { The organizing of the mass movement's structure. } \\
\text { The selection of the form of the opposition strategy. }\end{array}$ \\
\hline 2 & $\begin{array}{l}\text { Actor (Samin } \\
\text { people) }\end{array}$ & $\begin{array}{l}\text { Live in, } \\
\text { In-depth Interviews }\end{array}$ & $\begin{array}{l}\text { The Samin people's reasoning in rejecting the cement factory. } \\
\text { Participation in the demonstrations. }\end{array}$ \\
\hline 3 & $\begin{array}{l}\text { Supporting } \\
\text { actors: Kendeng } \\
\text { farmers }\end{array}$ & $\begin{array}{l}\text { Live in, } \\
\text { In-depth Interviews }\end{array}$ & $\begin{array}{l}\text { The Kendeng farmers' contributions to the opposition movement. } \\
\text { Commitment and support (material and non-material). }\end{array}$ \\
\hline 4 & $\begin{array}{l}\text { Stakeholder } \\
\text { NGOs }\end{array}$ & $\begin{array}{l}\text { Interviews with } \\
\text { LBH}^{*} \text { Semarang, } \\
\text { Walhi }^{* *}\end{array}$ & $\begin{array}{l}\text { The motivation for Non-government organisations' (NGO) involvement. } \\
\text { The level of involvement in determining the direction and movement strategy } \\
\text { The form of action support and advocacy }\end{array}$ \\
\hline 5 & $\begin{array}{l}\text { Government } \\
\text { Stakeholders }\end{array}$ & In-depth Interview & $\begin{array}{l}\text { The reason for the acceptance of the cement company investment } \\
\text { Regulations which were issued } \\
\text { The responses to the rejection of the cement factory }\end{array}$ \\
\hline 6 & $\begin{array}{l}\text { Police } \\
\text { Stakeholders }\end{array}$ & $\begin{array}{l}\text { Police reports in the } \\
\text { media }\end{array}$ & $\begin{array}{l}\text { The police role in watching over the conflict in the establishment of a cement } \\
\text { factory } \\
\text { Police attitudes and biases }\end{array}$ \\
\hline
\end{tabular}

* Legal Aid Institute (LBH - Lembaga Bantuan Hukum)

** Indonesian Environmental Society (Walhi - Wahana Lingkungan Hidup Indonesia)

community organizations, which are hierarchical and integrating, and divided into Neighbourhood Association (RT - Rukun Tetangga) and hamlets. Samin people do join in the RT and hamlet groupings but only to ensure good social relations with neighbours and friends.

Samin teaching found in this study, is the same as in previous studies which, in essence, is the teaching of a simple life in behaviour, speaking and acting (Ba'asyin \& Ba'asyin, 2014; Hutomo, 1996; Munawaroh, Ariani, \& Suwarno, 2015; Susilo, 2003; Suyami, 2007; Wibowo, 2011). A principle of Samin community life, which is simplicity, makes for an unaffected lifestyle, speaking plainly and upholding values of honesty and truth (Kirom, 2011; Larasati, 2011; Suhandano, 2015; Suyami, 2007). Samin people choose the work of farmers because this work produces income consistent with that which is worked upon, for example rice is what is harvested. They even choose organic agriculture as a livelihood which accords with natural law, that is supplying food in a natural way. The principle of life which has a basis in organic agriculture leads Samin people to venerate environmental protection. Because of that, they strive to protect their land to the best they can with methods of diajeni (respecting), diopeni (maintaining) and demenung (using as needed) (Asrawijaya, 2020).

Samin ideology emphasizes a natural life and rejects a life dependant on the state and the market, making Samin people a threat to the state. In the New Order period, they were viewed as dissidents because they were reluctant to pay taxes, and be a part of the Javanese community (Peluso, 1992). As a consequence, their rights as citizens were difficult to meet, as such there was no acknowledgement of their ideology, land ownership, certificate of residency, and marriage rites. They even became stigmatized as farmers who were supporters of the Indonesian Communist Party (PKI - Partai Komunis Indonesia).

In the reformation period, Samin people are also facing an expanding role of the regional and village governments in rolling out development programs. Many programs are coming into the community, and Samin people are made a target of development. They are also urged to participate in development, and in the recruitment of village officials as a celebration of democracy. Nevertheless, Samin people have a passive attitude and withdraw themselves from being part of a development target. As an example they do not want to take part in the National Program for Community Empowerment of Independent Villages (PNPM Mandiri Perdesaan Program Nasional Pemberdayaan Masyarakat Mandiri Perdesaan) because their aim is to remain living autonomously from their farming. For Samin people their 
ideology teaches them to live as subsistence farmers, to avoid politics so as not to regulate or be regulated by others, and avoiding development projects so that their lives are not dependent on assistance.

\section{Gunretno's Background as a Leader in the Samin Community}

At the end of the New Order period, the obligation of Samin people to have an identity card, plus the legalities of land and house ownership had raised awareness in its circles to have representatives who could speak for them in communicating with government. A representative who later became popular among several representatives in a number of communities was Gunretno. He was popular because he had married Hartati, who was the grandchild of a custodian of traditions greatly respected by the Samin community in Bombong and Bacem Hamlets.

At the beginning of the reformation period, Gunretno continued his role as a representative of the residents when organizing citizenship matters with the regional and village governments. He was also trusted by the village government to assist the residents to organize identity cards, family cards and several residence administrative matters. Because he was popular as a residents' representative, non-government organizations also often requested him to be a part of the traditional community capacity strengthening program.

Gunretno later showed promise as an activist. At the regency level, he took part in establishing Advancing Farm Workers (Karya Tani Maju) in 1999. This organisation helped farmers who were flood victims. In 1999 the Community Participation Development Forum (FPPM - Forum Pengembangan Partisipasi Masyarakat) was also born, in Jakarta. The forum became a communications and cooperation venue between nongovernment organizations activists at the local level. Several times this forum invited Gunretno to share his ideas and experience in working alongside residents. On the other hand Gunretno, through this forum, matured as an activist. He was increasingly carried along a path as a Samin tradition activist. Along with his siblings, Gunarti and Gunarto they were known as the Samin activists.

Due to the support of FPPM and several NGOs such as Walhi, it often gave spirit to the Samin struggle to demand acknowledgement of its customary rights. Gunretno then became aware that Samin ideology would continue to live if it was struggled for by advocative means and by developing residents' awareness to get organised in a participative way. In other words, within a social action theory framework, Gunretno had absorbed a way of thinking within a new action structure which had as its source civil society organizations and social movements (Kinseng, 2017; Davis et al., 2005; Giddens, 1984).

After joining with FPPM, Gunretno also joined several organizations which were concerned about village development and traditional community empowerment, such as the Archipelagic Traditional Community Alliance (AMAN - Aliansi Masyarakat Adat Nusantara), Walhi, and the Indonesian Farmers Union (SPI - Serikat Petani Indonesia). Because of these various social networks, Samin opposition under Gunretno's leadership did not undertake civil disobedience with methods of self-isolation as had been done by the Samin founder. Gunretno, on the contrary, used social networks, actively opposing the state.

Gunretno's active role in social movements was strongly supported by Samin members. They felt the importance of Gunretno being close to NGOs. Gunretno also used this trust both from the Samin members and from various NGOs. Gunretno continued to build his social capital and, for example established the Pati Farmers' Union (SPP - Serikat Petani Pati) in 2002. This organization worked to strengthen the autonomy and harmony of farmers. He also established the Environmental Care Community Forum in 2006. This forum changed to the Kendeng Mountains Care Community Network in 2008.

Through various farmers' associations he belonged to, Gunretno expanded his social network as a result becoming ever more trusted as a Samin figure in Pati Regency and in Indonesia. On the other hand, Samin members increasingly needed Gunretno as a leader. Gunretno's role as an activist for Samin members was at the time the government gave support to the development of a cement factory, which threatened the environment, Samin people's livelihood and the population in Kendengan Mountains.

By learning from NGOs, Gunretno was able to motivate his members to oppose by means of participation. Due to the support from NGOs for example, he was able to make a film of the struggle of the Samin people opposing the establishment of a cement factory which was disseminated via social media. Guided by NGOs, he also was able to make songs of struggle which increased the militancy of the Samin members and of their supporters in rejecting the establishment of a cement factory. The disseminating of the video of struggle, Samin Vs Semen (Samin Vs Cement) on social media it also increased public sympathy.

The increasing of the power of the struggle, in a participative way, was done by Gunretno in concert 
with his siblings. They interpreted the Samin ideology as a life choice in harmony with a farmer's life such as putting at the forefront the conservation of natural resources. The threat of environmental damage and the depletion of water sources were reasons they rejected the development of a cement factory. Samin members and non-Samin were able to unite to oppose the cement factory, in a participatory way, when the threat of water scarcity become a shared threat. With this being the case, Gunretno, as agency, had highly creative powers to generate opposition by participative means (Heredia, 2017; Schock, 2013).

Gunretno was also able to delegitimize the community group in Pati, who in contrast, took an attitude of supporting cement development with the reason it created work opportunities for residents. Gunretno delegitimized this by stressing that Samin people on the contrary took a critical position on preserving the environment as a result rejected development and its damaging of resources and the livelihood for their children and grandchildren.

Gunretno also had a shrewdness in effectivel using social capital. He used NGO networks as well not just for demonstrations but to oppose cement companies through the state court system. With the support of the NGOs, the Samin people were able to seize a victory in the courts when opposing the cement factory development.

Gunretno was also steeped in the Samin ideology which rejected violence in struggling for fate. This choice of non-violence was strengthened by studying of various NGOs that the victory of a movement is the ability to conduct non-violent action, this made the government and in particular the police almost never oppress its demonstrators with violence means.

\section{Role of Agency in Samin Opposition to the Cement Factory Development}

The role of agency in the Samin movement is discussed in three cases, that is the role of agency at the time of the cement factory establishment plans for PT SG, PT SMS, and PT SI. The analysis of agency is presented by considering the role of the actor, and the stakeholders' responses. The success of agency is apparent from the postponing of the cement factories' development because of the welling up of mass opposition in a participative, non-violent way.

\section{The Semen Gresek Limited (PT SG) Cement Factory Establishment Plan}

The Samin people, under the leadership of Gunretno, were able to prevent the establishment of a cement factory at Sukolilo, Kayen, Margarejo and Gabus, Pati Regency. The provincial and regency governments gave support to the development of this cement factory. A number of regulations were issued which gave business approval for PT SG to operate such as: Decree Number: 591 of 2008 concerning Pati Regional Exploitation Area Approval; Decree Number: 540/039/2008 concerning Clay Group C Mining Exploitation Regional Mine, and Decree Number: 540 of 2008 concerning the Limestone Group C Mining Exploitation Region mine. Additionally, the company was supported by the Regent's Declaration No. 131 of 2008 concerning the Regional Zoning Plan (RTRW - Rencana Tata Ruang Wilayah), and the Governor of Central Java's Regulation of 2008 concerning the Sukolilo Preservation Karst Region Determination.

The Regional Government gave authority for the establishment of the cement factory with the expectation that the factory would lift the economy of the Pati community. This was because the cement factory would buy raw material from the people and create new jobs. Despite this, the Samin people opposed it because the cement factory had on the contrary been determined as being damaging to natural resources, and their livelihood in the agricultural sector. Gunretno opposed it at the outset by criticizing a number of the approvals which were made without any initial public consultation. In addition the approval was issued prior to a study of the environment impact (AMDAL - analisis mengenai dampak lingkungan).

Gunretno's critical position was supported by environmental NGOs and the traditional communities, and as a result contributed to making the Samin members give their full support. Finally, they took a legal path that is rejecting the legality of PT SG being allowed to construct a factory at Pati. In addition, Gunretno together with the Samin members, held a peaceful demonstration to build public opinion that they were not amenable to a compromise. Gunretno and Gunarto and youths were trained to to mobilize the masses by explaining why they must reject the building of the cement factory and the relevance of the peaceful demonstration so that they would not be pressured into violence by the government and police.

After strengthening collective awareness concerning the dangers of the cement factory for a livelihood based on agriculture, Gunretno formed a movement named the Kendeng Mountains Caring Community Network (JMPPK - Jaringan Masyarakat Peduli Pegunungan Kendeng) in 2008. Within the organization he emerged as the leader who brought together various groups who 
agreed to reject the development of a cement factory. Through JMPPK, the network members became united in their resolve and at the same time developed a strategy to conduct resistance without violence, and this strategy was in accord with the Samin ideology which places to the fore a controlled protest rather than an unruly one. Through JMPPK emerged Gunretno's, Gunarto's and the late Tarno's initiative to form a women's organization, the Simbar Wareh Environmentalist Women's Group (KPPL - Kelompok Perempuan Pecinta Lingkungan). The organization was formed as a realization of a concern to the threatening of sources of springs which are very much needed by mothers in managing their households. The organization was led by Gunarti while its advisor was Gunretno.

After JMPPK and KPPL were formed, Gunretno developed networks at the regional and national levels. He was able to obtain support from agrarian NGOs at the Regency level such as SPP, Advancing Farm Workers (Karya Tani Maju), at the provincial level were organisations such as Agrarian Communication Forum (FMKA - Forum Komunikasi Agraris), and at the national level, Agrarian Renewal National Committee (KNPA Komite Nasional Pembaharuan Agraria), Walhi, LBH, Higher Educational Institutions, environmental activists,
AMAN, National Commision on Human Rights (Komnas HAM - Komisi Nasional Hak Asasi Manusia), religious alliances, students and youths, workers alliances, and national figures.

With the establishment of a collective force from Samin members and the support of the various NGOs above, mass oppostion was conducted through open actions such as demonstrations, long marches, and casting of feet in cement. These field actions were accompanied by a variety of other actions such as theatre, poetry recitals, mocking words, yells, erecting command posts, wearing traditional clothes, carry a number of traditional farming implements, and prayers for the president. The largest action was conducted in 2009, when the Governor, Bibit Waluyo who planned to officially mark the constructing of the cement factory was opposed by JMPPK by various mass actions such as demonstrations followed by theatrical actions and other symbols of rejection such as words and satirical poetry and descending on the streets, burning old tyres and blocking roads.

Before Samin people, with the support of Kendeng and NGO farmers, had staged demonstrations, they opposed the cement factory construction through legal avenues. Gunretno learned from legal experts and requested their assistance. While pursuing legal claims,

Table 2. Initial Protest Actions to Oppose the PT SG Cement Factory Construction Plan

\begin{tabular}{|c|c|c|}
\hline No. & Description & Information \\
\hline 1 & Date of event & May 16,2009 , \\
\hline 2 & Role of agency & $\begin{array}{l}\text { Gunretno found a trigger which would arouse Samin members and Kendeng farmers to protest, } \\
\text { using the support of NGOs to give the protest public exposure. }\end{array}$ \\
\hline 3 & Trigger & $\begin{array}{l}\text { The Governor of Central Java, Bibit Waluyo, accompanied by the Regent of Pati, planned to } \\
\text { inaugurate the plan for the establishment of a cement factory at Pati. }\end{array}$ \\
\hline 4 & Strategy & $\begin{array}{l}\text { The demonstrators blockaded the Pati - Purwodadi route for two hours. The demonstrators also } \\
\text { set up banners "reject cement factory", carrying coffins as a symbol of rejection, and erecting a } \\
\text { command post to reject the cement factory at Sukolilo sub-district. }\end{array}$ \\
\hline 5 & $\begin{array}{l}\text { Total numbers of } \\
\text { demonstrators }\end{array}$ & $\begin{array}{l}\text { Around } 500 \text { people, comprising approximately } 200 \text { Samin people and } 200 \text { Kendeng farmers } \\
\text { with the remainder from the general public. }\end{array}$ \\
\hline 6 & $\begin{array}{l}\text { Participation of the Samin } \\
\text { community }\end{array}$ & $\begin{array}{l}\text { Almost all of the adult Samin members actively participated in the peaceful demonstration } \\
\text { action. }\end{array}$ \\
\hline 7 & Kendeng farmers support & Joined in by sending a delegation to the demonstration. \\
\hline 8 & $\begin{array}{l}\text { Response from the } \\
\text { government }\end{array}$ & Postponed the inauguration of the cement factory construction. \\
\hline 9 & $\begin{array}{l}\text { Response from the } \\
\text { company }\end{array}$ & $\begin{array}{l}\text { Looking at the large scale action which occurred, finally the SG Limited management } \\
\text { requested the delaying of the factory's construction. }\end{array}$ \\
\hline 10 & Police response & $\begin{array}{l}\text { The police detained nine residents, including four Samin people, one of whom was Gunarto, } \\
\text { the younger sibling of Gunretno when staging its rejection at Kedungmulyo Village. }\end{array}$ \\
\hline 11 & Outcome & $\begin{array}{l}\text { The Supreme Court (MA - Mahkamah Agung) reached a decision in } 2009 \text { for the cessation of } \\
\text { the cement factory establishment plan at Pati. }\end{array}$ \\
\hline
\end{tabular}


Gunretno prepared an action plan to hold demonstrations. Samin people with the support of Kendeng farmers, held demonstrations when Governor Bibit Waluyo visited Sukolilo to inaugurate the cement factory. Table 2 has details of how the dates were used as triggers, the role of Gunretno and members and the support from farmers and NGOs.

The peaceful demonstration action plan was well executed. The company and the police did not suspect that the residents would be so resolute in carrying out their rejection of the factory construction. Without causing any damage the Samin people remained consistent in rejecting the factory's construction because of its weak legal reasons and empiric reasons that their fate as farmers would also be threatened because of the threat of environmental damage. Finally, due to the demonstrations, at the State Administration Court (PTUN - Pengadilan Tata Usaha Negara), Semarang the Samin community won the court action, but later was defeated by PT SG at the State Administration Appeals Court (PTTUN Pengadilan Tinggi Tata Usaha Negara), Surabaya. In the end, the Supreme Court upheld the Samin community's legal claim forcing PT SG to leave Pati.

\section{Role of Agency in Samin Movement Opposing Sahabat Mulia Sakti (PT SMS)}

Subsequently PT SG moved to Rembang because it had lost against the Samin people's claim at the Supreme Court hearing. PT SMS, which is a subsidiary of PT Indocement, tried to enter Pati Regency to build a new cement factory at Kayen and Tambakromo sub-districts. The Cement Factory Development Plan was also supported by the regional government through factory establishment location approval No. 591/021 of 2011, then with mining business approval (ijin usaha pertambangan - IUP) No 591/608/2014, concurrently with limestone mining activity approval, IUP No. 545/002/2011 which was renewed in No 545/002/2014 and clay mining approval in IUP No. 545/001/2011 renewed in IUP No 545/001/2014.

Gunretno opposed the Cement Factory Development Plan for PT SMS by showing shortcomings in its legality. The cement company had in its pocket approval from the Ministry of ESDM Number $2641 \mathrm{~K} / 40$ / MEM/2014. Despite this, Gunretno and his colleagues knew that the Ministry of ESDM should not have issued these approvals because there was already a court decision which rejected the building of a cement factory. The approval from the Ministry of ESDM seemed to be a new approval, because it gave permission for a cement factory which would be built outside of the area disputed by the Samin people and the SG factory, where the court had decided in favor of the Samin people.

Seeing that the government continued to support the construction of a cement factory, Gunretno once again influenced the residents and Kendeng farmers' groups so as to mount opposition. Gunretno's argument was that the new factory would also exploit the karst region, a region which must be conserved. The Samin members in Rembang then submitted a legal objection to the Ministry of Energy and Mineral Resources. To provide a push along, so that the legal objection would be heeded by

Table 3. Protest actions opposing the SMS Limited Cement Factory Development Plan

\begin{tabular}{|c|c|c|}
\hline No. & Description & Information \\
\hline 1 & Time of event & 12 January 2015 \\
\hline 2 & Agency Role & $\begin{array}{l}\text { The agency initiated, mobilized, and facilitated the opposition movement in } \\
\text { undertaking actions in the field. }\end{array}$ \\
\hline 3 & Trigger & $\begin{array}{l}\text { The issuing of the cement factory construction approval supported by the German } \\
\text { parent company. }\end{array}$ \\
\hline 4 & Total and origins of demonstrators & 500 Samin people from three subdistricts, Tambakromo, Kayen, and Sukolilo. \\
\hline 5 & Samin community participation & $\begin{array}{l}\text { The Samin members were involved in various actions principally a long march and } \\
\text { feet casting, and delegated one of the Samin community members, that is Gunarti to } \\
\text { campaign in Germany. }\end{array}$ \\
\hline 6 & Opposition strategy & Hold a demonstration in the Pati Regency Government courtyard \\
\hline 7 & $\begin{array}{l}\text { Response from the government and } \\
\text { police }\end{array}$ & $\begin{array}{l}\text { The government defended the cement factory development plan by issuing new } \\
\text { regulations which supported this plan. }\end{array}$ \\
\hline 8 & Response from the company & $\begin{array}{l}\text { The company continued to approach the government so as the factory development } \\
\text { plan could be realized. }\end{array}$ \\
\hline 9 & Outcome & The cement factory development was postponed. \\
\hline
\end{tabular}


the court, Gunretno invited Samin members and Kendeng farmers' groups to undertake further peaceful protest actions. These protests were conducted at the front of the Pati Regency government offices from 12 January to 23 July 2015 . The protest action was continued with a boycotting on the northern beaches road route. These actions were also conducted with a long march to the Central Java Governor's and Regional Parliamentary offices.

The demonstration actions were able to increase the Samin people's movement and Kendeng farmers' popularity. Because of this, the factory's construction was delayed. To galvanize the Samin and Kendeng youth so as to be alert to the possibility of being split, Gunretno gave support for a village youth movement to establish organizations such as Bocah Angon (Vigilant Boys), Environmentalist Youth Community (Komunitas Pemuda Pemerhati Lingkungan), and Kendeng Adventure.

Demonstrative actions were able to influence the justice process. The Samin people won the case at the PTUN Semarang although at PTTUN Surabaya and at the MA the case was won by PT SMS. The defeat handed down at the MA, did not extinguish the struggle. Opposition continued to be mounted. They made themselves ready by compiling strong evidence for a review (PK - peninjauan kembali) of the cement factory development approval for SMS Limited.

\section{The Role of Agency in the Samin Movement Opposing Semen Indonesia (PT SI)}

After failing to construct its factory at Pati, PT SG shifted its factory location to Rembang, changing its name to PT SI. Rembang Regional Government gave approvals in Rembang Regency Decision No. 545 of 2010 concerning Mining Business Approval, Karst Exploration Approval in Decision Letter No. 545 of 2011, and mining location approval No. 591 of 2011.

The solidarity between the Samin members and the farmers Gunretno meant they continued to oppose the cement factory development plan even though its construction had shifted to Rembang. Gunretno conceived an opposition on a wider scale, a stronger strategy and even more extreme action. Supported by activists who agreed to reject the karst region exploitation for the cement factory, Gunretno and his colleagues planned demonstrations accompanied by theatrical actions. These public actions were done in several places such as in front of the Central Java Governor's Office, the Pati Regent's Office, the Pati Civic Square, Yu Patmi Building (Langgar $Y u$ Patmi $)^{1)}$, and the Kedungmulyo field. Opposition actions were conducted also in Jakarta, Bandung, and Semarang which attracted public sympathy evidenced by the attendance of artists, politicians, religious figures, punk kids, and music groups.

Table 4. The protest action against the PT SI Cement Factory Development at the State Palace

\begin{tabular}{|c|c|c|}
\hline No. & Description & Information \\
\hline 1 & Time of event & $\begin{array}{l}12 \text { April } 2016 \text { in front of the State Palace and on } 13 \text { March } 2017 \text { in front of the State } \\
\text { Palace and National Monument. }\end{array}$ \\
\hline 2 & Role of agency & $\begin{array}{l}\text { The agency conceived an opposition on a wider scale, a stronger strategy, and even more } \\
\text { extreme actions. }\end{array}$ \\
\hline 3 & Trigger & The cement factory development plan at Rembang. \\
\hline 4 & Strategy & $\begin{array}{l}\text { The action of self-harm was in the form of Samin members as a group cement casting } \\
\text { their feet in concrete in front of the state palace and the national monument. }\end{array}$ \\
\hline 5 & $\begin{array}{l}\text { Total participants and their } \\
\text { origin. }\end{array}$ & $\begin{array}{l}\text { Around } 20 \text { Samin people, } 35 \text { Kendeng farmers and dozens of participants from NGOs, } \\
\text { academics, students and youths. }\end{array}$ \\
\hline 6 & Community participation. & All the Samin activists in Pati and Rembang. \\
\hline 7 & Stakeholder support & Human Rights activists and environmental NGOs in Indonesia. \\
\hline 8 & $\begin{array}{l}\text { Responses from the government } \\
\text { and the police }\end{array}$ & $\begin{array}{l}\text { Issued an order for the conduct of a Strategic Environmental Study, and preventing police } \\
\text { pressure by violence. }\end{array}$ \\
\hline 9 & Response from the company. & $\begin{array}{l}\text { The company continue the factory development because it considered the MA and } \\
\text { Governor's decision letters only required the company to improve upon the AMDAL } \\
\text { documents. }\end{array}$ \\
\hline 10 & Outcome & $\begin{array}{l}\text { The emergence of the Supreme Court's } 2016 \text { judgement which decided in favour of the } \\
\text { Samin community claim in Rembang. }\end{array}$ \\
\hline
\end{tabular}


Apart from actions around cities, a Samin women's group also demonstrated in front of the State Palace, by casting feet in cement on 12 April 2016, and at the National Monument on 13 March 2017. In this phase the name Kartini Kendeng emerged, that is nine women who cemented their feet. Though this cement casting of feet, the Samin members got a positive response from the president with the issuing of an order that the cement factory construction be halted pending the results of an environmental study.

The Samin people's resolute actions in opposing the cement factory led to environmental activists for Indonesia Watch, providing support to the Samin people's representatives to protest at the German company which had joined in funding the cement factory. Gunretno delegated the task to Gunarti, to depart to Germany on 3 March 2017 to meet an invitation from an NGO, 'Watch Indonesia' in a series of roadshow activists with the screening of the film Samin Vs Semen across 10 German cities over three weeks. The activity was continued with a scientific dialogue between Gunarti with activists and students in Germany. Other agenda items were a discussion with Heidelber Cement management to review and cancel plans to exploit the Kendeng Mountains (Putri, 2017).

Finally the struggle of the Samin people to reject the cement factory development in Rembang got results. The advocacy had a loss in the courts at the first and second levels. Despite this, in the MA session, they won their claim on 5 October 2016 and as a result the environmental approvals issued for PT SI had to be cancelled.

\section{CONCLUSION}

This paper depicts the Samin opposition movement against the construction of a cement factory using Action Theory and in particular Agency Theory, with the result being that the strong role of Gunretno is portrayed as the motivator and director of the building of an advocative and demonstrative opposition, absent of violence.

Gunretno became a powerful agentcy because he underwent a process of gaining a literacy in social movements thatwhich had grown in the reformation period. This literacy enabled Gunretno to gain the capacity toas a support for Samin people in facing a growing threat fromof the state regime and market control. Because of that, when the cement factory development plan appeared, Gunretno emerged as a leader who was trusted by members of his community to oppose it.

Gunretno became a leader who could get support from civil society organization circles. HisGunretno's instilled ideology stemmedis from a civil society movement thatwhich opposes extractive industry operations because of thethey damage they incur on the environment. This civil society support increased the Samin community's trust, enabling them to carry out nonviolent, advocative and demonstrative protest actions. Gunretno made the Samin movement, opposing the cement factory, become a strong civil society movement, one that which was able to delegitimize the development of the cement factory development, which threatened their right to live in the Kendeng Mountains.

There are two matters thatwhich are new findings in the study of the Samin in this study. First, clearly the role of agency from youth groups in strengthening the Samin people's struggle toin opposeing the corporations which threateninged environmental conservation and their livelihood with its basis in agriculture. Second, the agency in the Samin community were those who came out of a tradition to oppose passively, to that of opposing openly and advocatively, with the as a result being that the Samin people's opposition to the corporations was different to to the earliery generation's indirect and cultural resistance.

Even with theseAlthough making new findings, this study diddoes not look atgive attention to the Samin community members' participation, and the emergence of pro-cement movements in resident circles in the Kendeng Mountains. Future studies need to focus on issues and themes of participation, conflicts between residents in responding to the expansion of cement companies, and the successes and failures of cement factories that use political economy to dominate local communities.

\section{ACKNOWLEDGEMENTS}

This article is a small portion of Enkin Asrawijaya's dissertion field data which was rewritten with Bambang Hudayana as the first supervisor. Bambang Hudayana enriched the discussion of the role of agency and gave relevant literature support. A thank you is extended to Dr. Pujo Semedi Hargo Yuwono, MA, as the co-supervisor who has provided guidance in the writing of the disertation and has stated there there is no requirement for inclusion in the research team.

\section{ENDNOTES}

1) This building is a centre bequeathed by $\mathrm{Yu}$ Patmi to JMPKK for opposing limestone mining and the construction of a cement factory 


\section{REFERENCES}

Antlov, H. (1995). Exemplary centre, administrative periphery: Rural leadership and the New Order on Java. Surry: Curzon.

Asrawijaya, E. (2020). Gerakan Ekopopulisme komunitas Samin melawan perusahaan semen di pegunungan Kendeng. Jurnal Sosiologi Pendidikan Humanis, 5(1), 35-47.

Azhima, A. F. (2011). Keberhasilan gerakan Zapatista di Meksiko (1994-2009): Analisa keterhubungan dengan masyarakat sipil global. Depok: UI Press.

Aziz, M. (2012). Identitas kaum Samin pasca kolonial. Pergulatan negara, agama dan adat dalam pro-kontra pembangunan pabrik semen di Sukolilo, Pati, Jawa Tengah. Kawasitra, 2(3), 225-328.

Ba'asyin, A. S., \& Ba'asyin, M. A. (2014). Samin mistisisme petani di tengah pergolakan. Semarang: Gigih Pustaka Mandiri.

Benda, H. J., \& Castles, L. (1969). The Samin movement. Bijdragen Tot de Taal-, Land-En Volkenkunde van Nederlandsch-Indië, 125(1969), 207-216, 218-240. https://doi.org/10.1007/978-94-015-3631-8

Bourdieu, P. (1990). Structures, habitus, practices. In The logic of practice (pp. 52-65). Cambridge: Polity Press.

Buechler, S. M. (1995). New social movement theories. The Sociological Quarterly, 36(3), 441-464. Retrieved from http://www.jstor.org.ep.fjernadgang.kb.dk/ stable/4120774

Butler, M. (2006). Revolution and the ritual year: Religious conflict and innovation in Cristero Mexico. Journal of Latin American Studies 38(3), 465-490.

Cohen, J. (1985). Strategy or identity? New theoretical paradigms and contemporary social movements. Journal of Social Research, 52(4), 663-716.

Darmastuti, R. (2015). Gerakan sosial tanpa kekerasan (Gerakan sosial masyarakat Samin terhadap rencana pembangunan pabrik semen di Sukolilo, Pati). Pax Humana: Jurnal Humaniora Yayasan Bina Darma, 2(3), 189-204.

Davis, G. F., McAdam, D., Scott, W. R., \& Zald, M. N. (2005). Social movement and organization theory. Cambridge: Cambridge University Press.

Faturrohman, D. (2003). Hubungan pemerintah dengan komunitas Samin. In Agama Tradisional. Yogyakarta: LKiS.

Fauzanafi, M. Z. (2012). Inventarisasi dan kajian Komunitas Adat Sedulur Sikep, Desa Sumber, Kecamatan Kradenan, Kabupaten Blora. Yogyakarta: Balai Pelestarian Nilai Budaya.

Giddens, A. (1984). The constitution of society: Outline of the theory of structuration. Cambridge: Polity Press.

Harsasto, P. (2020). Membedah diskursus modal sosial dan gerakan sosial: Kasus penolakan pabrik semen di Desa Maitan, Kabupaten Pati. Politika: Jurnal Ilmu Politik, 11(1), 18-30. https://doi.org/10.14710/ politika.11.1.2020.18-30

Hartati (2012). Kewenangan pemerintah daerah dalam pengelolaan pertambangan mineral dan batubara. MMH, 41(4), 529-539.

Heredia, M. I. de. (2017). Creative survival as subversion. In Everyday resistance, peacebuilding and state-making (pp. 153-178). https://doi. org/10.7765/9781526108784.00014

Hudayana, B., Suharko, \& Widyanto, A. B. (2020). Communal violence as a strategy for negotiation: Community responses to nickel mining industry in Central Sulawesi, Indonesia. The Extractive Industries and Society, 7(4), 1547-1556. https:// doi.org/https://doi.org/10.1016/j.exis.2020.08.012

Hutomo, S. S. (1996). Tradisi dari Blora. Citra Almamater. Kaoma, K. J. (2016). African religion and colonial rebellion: The contestation of power in Colonial Zimbabwe's Chimurenga of 1896-1897. Journal for the Study of Religion, 29(1), 57-84.

King, V. T. (1973). Some observations on the Samin movement of North-Central Java. Suggestions for the theoretical analysis of the dynamics of rural unrest. Bijdragen Tot de Taal-, Land- En Volkenkunde / Journal of the Humanities and Social Sciences of Southeast Asia, 129(4), 457-481. https://doi. org/10.1163/22134379-90002714

King, Vi. T. (1977). Status, economic determinism and monocausality: more on the Samin. Bijdragen Tot de Taal-, Land-En Volkenkunde, 133(2/3), 350-354.

Kinseng, R. A. (2017). Strukturgensi : Sebuah teori tindakan. Jurnal Sosiologi Pedesaan, 5(2), 127-137.

Kirom, S. (2011). Ajaran Moral Masyarakat Samin dalam Perspektif Etika: Relevansinya bagi Pengembangan Karakter Bangsa. Universitas Gadjah Mada.

Korver, A. P. E. (1976). The Samin movement and millenarism. Bijdragen Tot de Taal-, Land- En Volkenkunde / Journal of the Humanities and Social Sciences of Southeast Asia, 132(2), 249-266. https:// doi.org/10.1163/22134379-90002642

Kumar, K. (2014). Confronting extractive capital: Social and environmental movements in Odisha. Economic and Political Weekly, 49(14), 66-73.

Larasati, T. A. (2011). Pola pengasuhan anak komunitas Samin Sedulur Sikep Dukuh Tambak, Desa Sumber, Kecamatan Kradenan Blora. Patrawidya. Seri Penerbitan Sejarah Dan Budaya, 14(2).

Moyo, S. (2005). The land question and the peasantry in Southern Africa. In Politics and social movement in an hegemonic world: lessons from Africa, Asia and Latin America. Retrieved from http://bibliotecavirtual.clacso.org.ar/clacso/sur- 
sur/20100711022553/13_Moyo.pdf

Mulyadi, M. (2013). Empowerment of indigenous people in development (Indigenous people case studies in Battang Palopo City South Sulawesi). Jurnal Penelitian Dan Ekonomi Kehutanan, 10(4), 224-234.

Munawaroh, S., Ariani, C., \& Suwarno (2015). Etnografi masyarakat Samin di Bojonegoro. (potret masyarakat Samin dalam memaknai hidup). Yogyakarta: BPNB.

Peluso, N. L. (1992). Rich Forest, Poor People Resource Control and Resistance in Java. Los Angeles: University of California Press.

Putri, P. S. (2017). Re-Claiming Lost Possessions : A Study of the Javanese Samin (Sedulur Sikep) Movement to maintan their Peasant Identity and Acces to Resources. University of Oslo.

Rahab, A. A. \& Soares, A. J. (2003). Perjuangan Amungme: antara Freeport dan militer. Jakarta: Elsam.

Rahab, A. A. (2010). Heboh Papua: perang rahasia, trauma, \& separatisme. Depok: Komunitas Bambu.

Robinson, K. (2016). Mining, land and community rights in Indonesia. In J. D. McCarthy \& K. Robinson (Eds.), Land and Development In Indonesia, Searching for the People's Sovereignty. Singapura: ISEAS Publising.

Ruswiastuti, R. M., Fauzi, N., \& Bacriadi, D. (1997). Penghancuran hak masyarakat adat atas tanah. Sistem penguasaan tanah masyarakat adat dan hukum agraria. Bandung: Konsorsium Pembaharuan Agraria.

Sacher, W., \& Baez, M. (2016). Extraktivisme Vs. Buen Vivir. In Dialog Global. (Vol. 6, pp. 26-27). International Sociological Association.

Saturnino, Edelmen, M., \& Kay, C. (2010). Gerakangerakan agraria transnasional. Yogyakarta: Sekolah Tinggi Pertanahan Nasional.

Savitri, L. A. (2013). Korporasi dan politik perampasan tanah. Yogyakarta: Insist Press.

Schock, K. (2013). The practice and study of civil resistance. Journal of Peace Research, 50(3), 277-290. https:// doi.org/10.1177/0022343313476530

Setiadi, Saraswati, A. R., \& Rosyid, N. (2017). Geger Sikep: Environmental (re) interpretation among the contemporary anti-cement movement in Kendeng, Central Java. Komunitas: International Journal of
Indonesian Society and Culture, 9(1), 13-28. https:// doi.org/10.15294/komunitas.v9i1.8673

Sewell, William H., J. (1992). A theory of structure : Duality, agency, and transformation. American Journal of Sociology, 98(1), 1-29.

Subarkah, \& Wicaksono, A. (2013). Perlawanan masyarakat Samin (Sedulur Sikep) atas kebijakan pembangunan Semen Gresik di Sukolilo Pati (Studi kebijakan berbasis lingkungan dan kearifan lokal). 171-194.

Subono, N. I. (2017). Dari adat ke politik: transformasi gerakan sosial di Amerika Latin. Tangerang: Marjin Kiri.

Suhandano (2015). Leksikon Samin sebagai cermin pandangan dunia penuturnya. Jurnal Litera, 14(1), 99-109.

Suharko (2016). Masyarakat adat versus korporasi: Konflik sosial rencana pembangunan pabrik semen di Kabupaten Pati Jawa Tengah periode 2013-2016. Jurnal Ilmu Sosial Dan Ilmu Politik, 20(2), 97-116. https://doi.org/10.22146/jsp.24776

Supraha, W. (1998). Baliku tersayang. Baliku malang. Potret otokritik pembangunan Bali dalam satu dasa warsa. Denpasar: Bali Post.

Susilo, J. (2003). Bahasa Samin, suatu bentuk perlawanan sosial. In Agama Tradisional. Yogyakarta: LKiS.

Suyami (2007). Kearifan lokal di lingkungan masyarakat Samin, Kabupaten Blora, Jawa Tengah. Yogyakarta: Kepel Press.

Tandon, R., \& Mohanty, R. (2002). Civil society and governance. New Delhi: Samskriti.

Wang, D. J., \& Soule, S. A. (2016). Tactical innovation in social movements: The effects of peripheral and multi-issue protest. American Sociological Review, 81(3), 517548. https://doi.org/10.1177/0003122416644414

Wibowo, A. (2011). Strategi Masyarakat Samin dalam Mempertahankan Keseimbangan Ekologis. Berk. Penel. Hayati, 4E, 35-42.

Widodo, A. (1997). Samin in the new order: the politics of encounter and isolation. In J. Schille \& B. Schiller (Eds.), Imagining Indonesia: cultural politics and political culture (pp. 261 - 187). Ohio: Center for International Studies. Ohio University.

Winarno, S. (2003). Samin: ajaran kebenaran yang nyeleneh. In Agama Tradisional. Yogyakarta: LKiS. 